\title{
Surveillance \& Society Seeing and Not-Seeing: Race and Body-Worn
Cameras in Canada
} Article

\section{Amanda Glasbeek}

York University, Canada

aglasbee@yorku.ca
Mariful Alam

York University, Canada

marifula@yorku.ca

\section{Katrin Roots}

University of Manitoba, Canada

katrin.roots@unmanitoba.ca

\begin{abstract}
This paper explores the racial dimensions of police body-worn cameras (BWCs) in Canada and the contested politics of seeing that they raise. By drawing on interview data with four Canadian police services and analyzing them through the work of anti-racist and anti-colonialist scholars, we argue that BWCs are engaged in the act of not-seeing the state violence that makes racialized communities vulnerable to police brutality in the first place. To include the politics of not-seeing in the story of BWCs changes our understandings of policing's new visibility and the potential promise of "policing on camera."
\end{abstract}

\section{Introduction}

In an episode of the popular television show Scandal, entitled "The Lawn Chair," the lead character Olivia Pope (Kerry Washington), a Washington "fixer," is called to a police scene to help calm a potentially riotous situation (Verica 2015). At the scene is an armed, middle-aged black man sitting in a lawn chair astride his dead son's body. His son had been shot by police. Believing his son innocent, and the victim of police misuse of deadly force, the father refuses to leave his son's body to his killers. For their part, the police claim that the young man had a knife with which he threatened the police officer who fatally shot him. Sure enough, a knife is found in the dead man's possession. At first, Pope, a black woman herself, attempts to coax the father out of the lawn chair at the behest of the city police chief who has hired her to help defuse the situation. Over the course of the episode, however, Pope's racial loyalties are tested: is she a member of the predominantly white elite whose power structures over-determine the outcome of such encounters, or is she a black woman whose own experiences of racism make her a useful ally to the angry black community gathered to protest the shooting death of yet another young black man? In the end, this agonizing personal decision for Pope is resolved through access to surveillance footage, which reveals that the police version of events is a concoction: the knife had been planted after the fact, and the young man had been shot in cold blood by a racist white police officer. At the end of the episode, the President of the United States (Tony Goldwyn) pledges to authorize the immediate deployment of body-worn cameras to all American law enforcement agencies (Verica 2015).

In this ripped-from-the-headlines episode, "The Lawn Chair" neatly captures many of the key issues that have animated the introduction of body-worn cameras (BWCs) to North American police services, offering both a synopsis of the past and a prediction for the future. Originally aired on March 5, 2015, the episode followed closely on the heels of the police-caused death of Michael Brown in Ferguson, Missouri (August 9,2014 ) and the heightened racial tensions that followed, as well as the subsequent White House directive to US Congress to allocate $\$ 75$ million to US police for the purchase of 50,000 body-worn cameras (Wing 2015). In its recounting of the importance of BWCs, Scandal presents them as a response to increasingly 
vocalized concerns about police use of racialized violence. Moreover, these concerns are not limited to the fact that police use deadly force against citizens of colour, especially young black men, but that they also lie about these events, closing ranks against public scrutiny and resisting oversight in favour of image management. "The Lawn Chair" juxtaposes the dramatic and heated exchanges between police and the black community with the calm and neutral role of video. The message is clear: unconnected to any "side" in this political struggle, a video-recording can mediate conflict by resolving competing versions of the truth with its own steadfast, unbiased account. This ability of video to restore the truth, it is suggested, is the way forward for a racially divided America.

In contrast, recent academic engagement with BWCs has painted a less optimistic picture of their potential to produce a radical change in the ways that police function. A growing body of empirical scholarship, focusing largely on the impact of BWCs on both officer and citizen behavior and attitudes (for an overview, see Lum et al. 2019), ${ }^{1}$ along with more qualitative studies on the sociolegal implications of BWCs (see, for example, St Louis, Saulnier, and Walby 2019; Newell 2019, 2016; Taylor and Lee 2019; Adams and Mastracci 2017; Beutin 2017; Gates 2016; Lippert and Newell 2016; Brucato 2015; Evans 2015; Wasserman 2015; Schaefer and Steinmetz 2014), collectively caution against over-simplistic reliance on the ability of cameras to render objective views of citizen-police encounters. Additionally, they emphasize the need for thoughtful and sustained oversight in the context of the increasing surveillant capacities of local police. Largely absent from these important critiques, however, is the role played by race in the implementation and workings of BWCs. ${ }^{2}$ In this paper, we explore the racial dimensions of BWCs and the contested politics of seeing that they raise.

The racialized dimensions of BWCs and policing expectations are surprisingly understudied. Despite a fourteen-fold increase in publications on BWCs between 2014 and 2019 (Lum et al. 2019: 96), and despite the fact concerns about racist policing are at the heart of the public's desire for BWCs, as illustrated by Scandal, to date "we know nothing about the effects [of BWCs] on disparate outcomes in policing" beyond speculation (Lum et al. 2019: 102). Given that this is "one of the most important questions about BWCs," Lum et al. (2019: 102) conclude that "such research should be a priority for policing scholars." This article begins to address this lacuna by sketching out the Canadian context for BWCs and, in particular, by focusing on the ways that race shapes the possibilities of what BWCs can do. Drawing on interview data with four police services gathered as part of a broader project on BWCs in Canada, and analyzing them through the work of anti-racist and anti-colonialist scholars, we argue that BWCs are engaged in the act of not-seeing the state violence that makes racialized communities vulnerable to police brutality in the first place. To include the politics of not-seeing in the story of BWCs changes our understandings of policing's new visibility and the potential promise of "policing on camera."

After a brief discussion of our methodology, we locate the politics of not-seeing in the broader context of "policing on camera" (Sandhu and Haggerty 2017) before turning to the Canadian landscape and the introduction of BWCs to Canadian policing. Importantly, BWCs have been taken up much more slowly in Canada than elsewhere, and especially in comparison to the United States. We argue that the very cautious introduction of BWCs to Canadian policing results from a specifically police-driven definition of the relationship between race and policing. In particular, we show how race and racism are constructed by police as an absence in Canadian police-community relations, a narrative that structures what BWCs can, and cannot, see. While community and social justice groups tend to argue that BWCs have the potential to make racism visible, police argue that these same cameras will evidence not only a lack of racism but also a police professionalism that protects against discriminatory policing. These profoundly different definitions of what

${ }^{1}$ Lum et al.'s (2019) survey of BWC literature categorizes the field into six major trends: the impact of BWCs on officer behaviour; officer attitudes about BWCs; the impacts of BWCs on citizen behavior; the impact of BWCs on citizen and community attitudes about police or cameras; the impact of BWCS on criminal investigations; and, the impact of BWCS on police organizations. The lion's share of research to date, however, has focused on police and/or citizen/community approaches to BWCs.

${ }^{2}$ Lyndsey Beutin's (2017) work is an important exception, and will be discussed later in the article. 
police worn cameras will "see" raise important questions about the future of BWCs in Canada. By keeping race at the forefront of our analysis, we aim to demonstrate the ways that, instead of serving as a neutral observer that can address racial divisions with respect to policing, as Scandal hopefully suggested, BWCs hold the potential for exacerbating racial tensions between Canadian police and the various communities they ostensibly serve.

\section{Methodology}

The data presented here are based on one-on-one interviews conducted with participants from four Canadian policing services - Thunder Bay and Toronto in Ontario and Edmonton and Calgary in Alberta - that were gathered as part of our larger research project on BWCs in Canada. Our broader purpose is neither to determine a causal relationship between BWCs and police-citizen interactions nor to create policy recommendations about what conditions need to exist in order for BWCs to improve policing. Rather, we draw on Kelly Gates' (2011: 5) argument that "[t]he introduction of new surveillance technologies... does not happen seamlessly or automatically, instead presenting major logistical, technical, and political challenges involving conflicts and negotiations among various vested social actors." Accordingly, we focus on the contested meanings and negotiations that have led to, and structured debates about, BWCs in Canada, especially in the context of heated public dialogue about policing practices, race, and accountability. In other words, we are less interested in whether BWCs work than in the work that BWCs do.

To this end, we conducted interviews with a broad group of Canadian stakeholders between September 2016 and June 2018. In total, we interviewed thirty-eight police employees, including twenty-six front-line officers, eight supervisors (Superintendents and Inspectors), and four senior policy personnel. All police participants had experience with BWCs through local pilot projects experimenting with the technology. In addition, we interviewed three current and former members of police oversight organizations; six legal actors, including Crown and defense attorneys; nine community organizers and anti-racist activists (e.g., from Black Lives Matter and municipal copwatch groups); and seven members of privacy organizations (the Canadian Civil Liberties Association and the Ontario Office of the Information and Privacy Commissioner). The semi-structured interviews ranged from one to two hours in length and were recorded, transcribed, and coded through Nvivo software. We conducted the interviews using open-ended questions that ranged from general inquiries (i.e., "What do you think are the main benefits or limitations of BWCs?") to more subjective questions (i.e., "What relationship, if any, do you think exists between BWCs and citizen videos of policing?") to more specific questions about the current climate of police accountability and legitimacy (i.e., "Do you think BWCs can help to address problems between police and racialized communities?").

We focus exclusively on police responses here largely because of the disproportionate power police have to define the future of BWCs. This is especially true in Canada, where an absence of any federal or provincial statutory governance or oversight of BWCs means that each individual police service has been left to its own devices to sort out, experiment with, consult on, and develop policies for this new technology (Bud 2016). ${ }^{3}$ Thus, how Canadian police understand the purpose and significance of BWCs matters a great deal for their potential uptake as a new policing technology. To protect the confidentiality of our participants, we have (in random order) labelled the four police services where we conducted interviews as Region 1, 2, 3 , or 4, and interview subjects are known only by the number assigned to them (e.g., "Participant 1" or "Participant 2"). Despite some important differences between the varying jurisdictions, our data reveal

\footnotetext{
${ }^{3}$ In July 2019, British Columbia developed provincial standards for the use of body-worn cameras, making it the only province to date to do so. The policy addresses issues such as conducting a privacy impact assessment, officer training, notification, and retention (see Government of British Columbia 2019). However, currently, all police services active in BC, including the RCMP, have rejected the use of BWCs. The only other guidelines for the implementation of body-worn cameras in Canada comes from the federal Office of the Privacy Commissioner of Canada's 2015 document Guidance for the Use of Body-Worn Cameras by Law Enforcement Authorities. While all police services piloting BWCs have consulted these guidelines, they have no enforcement authority.
} 
common themes. Most notably, despite the size or complexity of the police organization, and regardless of the different demographic communities they serve, a central finding to emerge from the police interviews as a whole is that Canadian police do not have a sense of urgency about BWCs as an accountability mechanism, especially with respect to race. The absence of any urgency in addressing racial disparities in policing, including through the use of BWCs, means that new meanings and purposes have been crafted to explain the relevance of this new technology. At the same time, police are aware that many citizens perceive them as racist. Rather than confront this allegation directly, Canadian police use BWCs as a slate on which to write their own understandings of race, racism, and policing and to fashion their own narratives about what they believe BWCS will "see." As we argue below, this police construction of the relationship between race, policing, and BWCs is better understood not just through an analysis of the changing nature of visibility but also through an appreciation of the politics of "not seeing."

\section{The New Visibility, Policing on Camera, and the Promise of Accountability}

The term "policing on camera" has two overlapping, but not synonymous, meanings. First of all, it can refer to the relatively new phenomenon of citizen-journalism, or acts of sousveillance through bystander videos of police-citizen encounters. ${ }^{4}$ The ability of any person to film, upload, and widely broadcast instances of police malfeasance has significantly changed the terrain of policing. It is this that Andrew Goldsmith (2010) referred to as "policing's new visibility," characterized by the increasing visibility of policing practices, and especially their use of force, and the decreasing ability for police to do their traditional "repair work" of narrating events in ways favourable to the police. Drawing on Richard Ericson's (1995) important work on the difference between police accountability and "account ability," Goldsmith (2010: 930) suggests that the new visibility could lead to "a huge reputational threat to contemporary police organizations." From Oscar Grant to Eric Garner to Alton Sterling to Philando Castille, among many other instances, the ability of bystander video to widely broadcast police violence has helped contribute to the "disappearance of disappearances" in policing (Haggerty and Ericson 2000: 619; Goldsmith 2010). In each of these cases, the fact that there was video evidence that was not within police control or custody, and that appeared to show "raw footage" that was not mediated by police (Brucato 2015: 457), created serious public concerns and new dialogues about the legitimacy of police activities. As Margaret Beare (2014: 92) has argued, "The greatest threat to the legitimacy of the police may come when the 'norm' becomes to question the truthfulness of police statements not just by defence lawyers in court, but also on the front pages of our newspapers and when it is examined in detail in various inquiries."

Yet, police have adapted to the new reality of policing on camera. Bryce Newell's (2019: 67) multiyear study of two police services in the US Pacific Northwest finds that between $70 \%$ and $80 \%$ of officers surveyed "reported being 'very comfortable' or 'somewhat comfortable' with civilians recording them while they worked." Gregory Brown (2016: 307) finds, through two case studies with Canadian urban police services, that an awareness of ubiquitous citizen video capacities has "tempered" police use of force, such that bystander video now acts as "both a disciplining influence on their consciousness as they perform police work and as a significant deterrent against use of force misconduct." Ajay Sandhu and Kevin Haggerty's (2017) ethnographic study of front-line officers of the Edmonton Police Service (EPS) finds three different ways that police respond to public filming of their work: the "camera-shy" officers, whose concerns centre mainly on the lack of context provided by bystander videos; the "habituated" officers, for whom bystander videos are less of a concern because they acknowledge that the majority of their work is boring and uninteresting to most observers but who also believe that video evidence will usually demonstrate that they were doing their jobs properly; and, finally, those officers who saw strategic advantage in being filmed. For this latter group, being filmed in the public performances of their jobs was most likely to exonerate them from unfair criticism. Drawing further on this research, Sandhu (2016: 88; emphasis in the original) suggests, in contrast to Brown's (2016) findings, that policing's new visibility "may not be a form of

4 There is considerable literature on the ways in which citizen-video has impacted the ways police operate. Some of this literature is discussed in the body of this article, but the larger issue of the relationship between citizen sousveillance and policing more generally is beyond the scope of this paper. For excellent discussion, see, for example, Brucato (2016, 2015); Farmer and Sun (2016); Huey, Walby, and Doyle (2006); and Monahan (2006). 
disciplinary power, but a form of power that encourages police offers to act more disciplined" as they develop their own, media-savvy responses to the new visual reality (see also Sandhu 2017; Gates 2016).

The increasing likelihood of police to find themselves on camera has given rise to a second kind of policing on camera, manifested through BWCs. While it is fair to argue that the emergence of BWCs is a direct result of the expansion of cop-watching videos (Brucato 2015), it would be inaccurate to say that it is just another example of policing the police through video evidence. BWCs may have gained popular support because they appear to systematize the transparency of policing activity (Mateescu, Rosenblat, boyd 2016), but their uptake by North American police services illustrate how, for police, having their own cameras is an answer to the problems raised by bystander videos. For example, the 2014 Iacobucci Report, commissioned by the Toronto Police Service (TPS) to investigate police use of force, ${ }^{5}$ concluded that BWCs were an urgent matter for the TPS given the "now broad recognition, within the TPS and in the general public, that police officers should expect to have their interactions with citizens recorded at all times. The widespread availability of video cameras on smart phones has removed police control over publicity surrounding policepublic interactions and placed it in the hands of subjects, by-standers, and media outlets" (Iacobucci 2014: 255).

As Newell (2019: 72) argues, this anxiety about "the widespread availability of video cameras" is "rooted in information politics, as the perceived loss of context, and loss of control over how and when information about their work was disclosed, suggests that officers are losing power in their struggle to frame and control the narrative and explain their interpretation of events depicted on the video (their 'account ability')." In response, BWCs offer a number of advantages to police: they have the potential to provide a bigger window into police-citizen encounters so that such incidents may not be taken out of context; they are promised as a way of ensuring that unfounded citizen complaints disappear and to provide evidence to exonerate police from unfair criticism; and, they produce potentially useful media and court evidence of police actions (Newell 2019; Sandhu and Haggerty 2017; Sandhu 2016; Brucato 2015). ${ }^{6}$ In short, BWCs are a way for police to manage visibility rather than be managed by it.

These police-driven rationales for BWCs are notably different from citizens' expectations of the technology, which tend to focus on increasing police transparency, especially with respect to the use of police discretion and force with racialized communities. This difference is usually analyzed as a struggle over the definition of "accountability." As Benjamin Brucato (2015: 457) neatly summarizes, "[d]epending on the party, accountability has differing meanings and significance. For civilians concerned about police abuse, this assurance will offer protection from unnecessary and excessive force. For the police, accountability offers the opportunity to exonerate themselves and their agencies from false complaints." This is more than a difference of opinion. As Brucato (2015: 470; emphasis in the original) concludes, "[t]he video shot from the position of the officer is legally and culturally privileged. As such, rather than being just a new surveillance technology, on-officer wearable cameras work as counter-sousveillance technology." Lyndsey Beutin (2017: 6) adds that a "racialized way of seeing" fundamentally structures this uneven relationship between the competing definitions of accountability, arguing that because filmic evidence of police-citizen encounters is viewed through a broader and historically informed racialized context, "body worn cameras constitute reforms that threaten to strengthen liberalism's co-constitution with structural racism, rather than ameliorate its injustices." In the rest of this paper, we seek to continue the conversation about the role played by race in defining the policing advantage promised by body-worn cameras.

\footnotetext{
5 The Iacobucci Report is formally titled Police Encounters with People in Crisis: An Independent Review Conducted by the Honourable Frank Iacobucci for Chief of Police William Blair (Iacobucci 2014). It was commissioned by the TPS following a highly publicized incident of a police-caused death in Toronto that was captured on citizen video. More detailed discussion of the circumstances leading to this report appear in a later part of this article.

${ }^{6}$ See Brucato (2015) for an analysis of the ways that this worldview matches the advertising campaigns of the manufacturers and sellers of BWCs to police services, especially the lead supplier, Axon International.
} 


\section{Not-Seeing: Race and the Politics of Visibility}

While surveillance scholarship generally acknowledges that racially constituted groups experience surveillance differently, critical race scholars have noted that surveillance studies has been less attentive to the specifically racialized contours of seeing and visibility. As John Fiske (1998) has written, "surveillance is a technology of whiteness" (69) in which the links between seeing and knowing are conditioned by a racial order: "It may be a technological feature of the surveillance camera that enables it to identify a person's race, but it is a racist society that wants that information and that turns it into knowledge; technology can determine only what is seen, it is society and its politics that determines what is known" (85). This kind of narrative interpretation was nowhere more evident than in the Rodney King trial, which transformed a video of African-American King's beatings by white police officers into a story about police victimization at the hands of black male danger (Skolnick and Fyfe 2005; Crenshaw and Peller 1993). As Judith Butler (1993:16) writes, the Rodney King video was viewed within a "racially saturated field of visibility" that structured what was possible for a jury to "see."

Simone Browne's (2015) compelling study of the links between surveillance and specifically anti-black racism offers the historic context for surveillance as a racialized practice. Drawing on such examples as the architecture of the slave ship, slave branding and registries, plantation rules, and the enforcement of "lantern laws" in eighteenth century New York - which required "Negro and Indian Slaves" to carry a lit lantern after sunset, ostensibly in order to ensure, and maximize, their visibility-Browne connects the deeply racialized practices of American nation-building with the equally racialized history of surveillance. Beutin (2017) similarly argues that the origins of American policing in historical practices such as slave patrols, along with nineteenth century criminology that highlighted the significance of the visualization of criminal evidence and representations of the truth, and the more general historical and cultural formations that have led to the naturalization of the criminality of blackness together have produced a "racialized way of seeing" that over-determines the ways that video evidence of police brutality is produced, seen, and experienced. The hypervisibility of black persons, made possible through the surveillance undertaken by white persons, indicates that racism is not something that occurs merely as a result of surveillance but, instead, that a racial ordering is part of the rationale for surveillance in the first place.

The work of anti-colonialist and feminist scholar Andrea Smith (2015) draws out this argument in ways that are enormously useful for considering the new visibility of policing. Smith argues that, while surveillance studies has been inordinately focused on the politics of seeing, it has neglected to include within its ambit the ways that the surveillance state is itself a product of surveillance and, more specifically, of the surveillance of Indigenous bodies, a critical defining practice in the creation of the modern state: "A focus on gendered settler colonialism... foreground[s] how surveillance is about a simultaneous seeing and notseeing.... The colonial gaze that surveils native communities to monitor, measure, and account for their 'dysfunctional' behaviors conceals from view the settler colonial state that creates these conditions in the first place" (Smith 2015: 25-26).

It is, then, not just visibility, or even hyper-visibility, that is significant, but also that which is hidden from view and, especially, the state itself as it engages in the act of surveillance while remaining outside the field of vision. Collectively, these critical race analyses of surveillance draw our attention not just to what is seen and often hyper-visbilized - namely, racialized subjects - but also to what is not seen and, specifically, the deeply historicized practices of attempting to know, and to contain, racialized bodies. Moreover, as the historical work of Brown (2016), Beutin (2017), and Smith (2015) demonstrates, these anti-black and antiIndigenous models of surveillance constitute the building blocks of the contemporary surveillance state. This context places into question the promises of BWCs to provide transparency and accountability in relation to police actions. 


\section{Body-Worn Cameras in the Canadian Landscape}

In Canada, as elsewhere, a number of recent incidents involving police use of lethal force against racialized community members have triggered outraged public responses demanding a reckoning with racialized policing, including through the systematic introduction of BWCs for front-line officers. The most wellknown of these incidents is the shooting death of Sammy Yatim, an eighteen-year-old Middle Eastern man, killed by white officer James Forcillo on a downtown Toronto streetcar on July 27, 2013. While on the streetcar, Yatim had exposed himself to two young women sitting at the back of the car and pulled out a small switchblade with which he threatened other passengers before demanding they exit the streetcar. Within fifty seconds of police arrival on the scene, Officer Forcillo fired nine shots at Yatim. The first three shots fatally wounded him. Forcillo then fired a second round of six shots while Yatim was lying on the ground (and a second officer then tasered the dying Yatim). Three years later, Officer Forcillo was found guilty of attempted manslaughter for the second round of bullets and sentenced to six years imprisonment. ${ }^{7}$

As predicted by Goldsmith (2010), the existence of bystander video documenting the fatal encounter between Yatim and Forcillo was key to the emergence of widespread public concern about police accountability for their use of force. The police encounter with Yatim was captured by two independent bystander cell phone videos, which were uploaded and seen immediately and broadly: within less than fortyeight hours, just one of the videos had been viewed nearly half a million times (Andrew-Gee 2014; Rodriguez 2014). Public outrage was immediate, leading to, among other things, a review of police use-offorce, commissioned by the Toronto Police Service and headed by retired Supreme Court Justice Frank Iacobucci. One of the key recommendations to emerge from the Iacobucci Report was that front-line officers be equipped with BWCs (Iacobucci 2014). ${ }^{8}$

In the midst of this legitimacy crisis for the Toronto police, several other incidents of police use of force against men of colour continued to galvanize many members of the community and forced new discussions about policing more generally. The suspicious circumstances surrounding the 2014 shooting death of Jermaine Carby, a black passenger in a car pulled over for a random police check, led to similar public outcries and was the coalescing point for the formation of a Toronto chapter of Black Lives Matter (Gillis 2015). The 2015 fatal shooting of Sudanese immigrant Andrew Loku, who was shot within twenty-one seconds of the police's arrival at his apartment building, was another significant rupture of already tense relations between Toronto's black community members and local police (Warinca 2015). Nor were such incidents confined to Toronto. A CBC investigation into the Edmonton Police Service practices of street checks, otherwise known as carding, found that Indigenous people were six times more likely to be stopped by police (and Indigenous women nearly ten times more likely to be stopped than white women), and black people were five times more likely to be stopped than white people (Huncar 2017). In Thunder Bay, accusations of racist policing were sufficiently egregious to warrant an investigation by the Ontario Civilian Police Commission into the operations of the Thunder Bay Police Board. This investigation occurred simultaneously with an Ontario Independent Police Review Directorate (OIPRD) inquiry into systemic racism in the Thunder Bay Police Service (TBPS), which itself followed on the heels of a coroner's inquest into police (mis)handling of multiple deaths of young Indigenous people in Thunder Bay between 2001 and 2011 (Jago 2018; Mayor and Findlay 2018; Talaga 2017).

\footnotetext{
7 The number of news sources for the Yatim killing are too numerous to cite here. For a general overview, see Ontario Justice Education Network (2016). Officer Forcillo was originally tried on secondary murder charges, but the jury found him guilty of attempted manslaughter, specifically because of the second round of bullets (Hasham 2016). Forcillo appealed his sentence, but this appeal was finally denied in April 2018 (Fine 2018).

8 In recommending body-worn cameras, the Iacobucci Report (Iacobucci 2014) was repeating an earlier recommendation as it appeared in the Toronto Police Service's (2013: 58) internal document, the Police and Community Engagement Review (PACER) Report: "That the service... explore the possibility of equipping all uniform Officers with Body Worn Video (Body Cameras)." It was through the Iacobucci Report, however, that the public became familiar with the TPS' intentions to pilot the technology (Iacobucci 2014).
} 
The high-profile nature of events such as these meant that the argument for BWCs for Canadian policing became almost impossible to ignore. A 2016 CBC News poll found that $75 \%$ of Toronto residents believed that all officers should wear the technology, with a full $81 \%$ of respondents strongly or somewhat agreeing that "the prevalence of cameras will lead to more police officers being accountable for their actions" (CBC News 2016: para. 2). Of these respondents, over half (53\%) agreed with the statement that racism is a "serious problem" for the TPS (CBC News 2016, para. 15). Police services outside Toronto found themselves under similar pressure. Calgary Police Services were early adopters of the technology, also prompted by investigations into officer-involved shootings and in an effort to regain public trust (Doll and Tucker 2016). Indeed, since 2015, most major police services in Canada have investigated the use of BWCs, largely in response to populist demands for their implementation as a way to address eroding public trust in policing more generally.

Yet, despite the popular demand, and in contrast to what has transpired in the United States, Canadian police services have proceeded very slowly with BWCs. At the time of writing, only a handful of municipal police services have committed themselves to adopting the technology. Amherstburg Police Service was the first police service to implement them for all front-line officers, with thirty-one officers wearing them since 2016. ${ }^{9}$ Calgary, Canada's fourth largest municipal police service, rolled out 1,150 cameras in early 2019 after several years of difficulty with the technology (CBC News 2019). Fredericton Police Service in Nova Scotia piloted two cameras in 2017 and have decided to move forward with implementing the use of six cameras on a permanent basis (Global News 2018). In December 2018, the OIPRD released its report on the Thunder Bay Police Service, finding widespread evidence of systemic racism in the TBPS and recommending that TBPS adopt body-worn cameras immediately, suggesting that Thunder Bay may soon join the ranks of Canadian police services with BWCs (Office of the Independent Police Review Director 2018). Meanwhile, the Toronto Police Service, the largest municipal service in Canada, is still in the process of implementing them. Edmonton, Canada's seventh largest municipal service, piloted BWCs between 2011 and 2014 with largely negative evaluations, and has decided against standardizing the equipment for its officers. The Royal Canadian Mounted Police similarly piloted and rejected the use of BWCs for its officers, as have the Vancouver and Victoria police services in British Columbia, Halifax Police Service in Nova Scotia, and Montreal Police Service in Quebec. Some police services, including Hamilton, Ottawa, and Winnipeg have shown interest in BWC technology but have yet to proceed with a pilot as they continue to study the issue through the experiences of other police services. To date, then, BWCs are more of a potential in Canada than a reality. ${ }^{10}$

\section{The Policing View: Canadian Police on Cameras and Race}

A key reason for the delay in implementing police body-worn cameras in Canada stems, we argue, not only from technological or cost difficulties (which are not insignificant; see, for example, Laming 2017) but also from the fact that, in Canada, police do not tend to believe that there is a "race problem" to be resolved. As other studies of Canadian police have found (Chan and Chunn 2014; Tator and Henry 2006; Wortley and Tanner 2003), the police participants in our study tended to deny the existence of systemic racism within their organizations:

Systemic hatred - I just refuse to believe that every person - regular people - they've got kids, they've got families, they're from all different backgrounds. Somehow all of us are systemically racist and prejudiced? We have Aboriginal officers, we have Irish, Polish, Black officers, we have everything under the sun. How can we all be against something when we've got all the demographics covered? (Participant 25)

\footnotetext{
${ }^{9}$ Amherstburg is part of the Windsor census metropolitan area, Ontario. It has a population of 21,936, and a police service that numbers thirty-one.

${ }^{10}$ See postscript.
} 
Even more significantly, despite the fact that the public demand for BWCs in Canada was propelled by overtly racialized domestic incidents, Canadian police preferred to use American policing as a point of departure to defend their own, Canadian, brand of policing as different - and better - than that of their American counterparts, reinforcing a national narrative in which Canada is not plagued by racial, and especially anti-black, violence: 11

We learned very quickly from our research that there are vast differences between policing in Canada and policing in the United States. But much of the negativity [toward police] that exists today, via things like YouTube and other social mediums, is US based. I think that's unfortunate. Mostly because I think it does a disservice to the really good work that's being done throughout Canada in policing. (Participant 63)

The refusal to acknowledge the existence of racism as part of either policing in general or as the impetus for BWCs was further evident in what we refer to as the police "origin stories" of BWCs. Not only did Canadian police personnel in each jurisdiction differentiate themselves from their American counterparts, but they also constructed remarkably similar narratives about why BWCs had been introduced to their respective workplaces:

Interviewer: Do you remember why [Region 1]... started implementing cameras? Was there... was there an incident or was it because...? Participant 49: Not so much an incident, but it was kind of the flavour of the day in the States. And they [Region 1 Police Service] kind of wanted to be the first ones in Canada to have both in-car and body-worns in conjunction with each other.

Participant 3: BWV [Body Worn Video] was tested in [Region 2] because it was a wave that was happening-you'd inevitably have to answer why you are or aren't using them. [Region 2 Police Service] is proactive so they tried it.

Participant 25: So that's how it started was I saw it in a magazine, I thought it was a good idea to get a more unbiased perception of what was occurring. It was just around that time that citizen videos with their cell phones were becoming very popular.... So that's how we started, seeing it in a magazine, thinking it's a good idea, asking permission and going from there.

Participant 63: It was not, for [Region 4], it wasn't politically motivated. It was motivated by [the] Chief, and by two reports... which suggested that the use of bodyworn technology in concert with the current in-car camera system that we use, perhaps would be a beneficial piece of technology to look into. So, from that we started.

These "origin stories" clearly de-racialize the arguments for BWCs. Instead, these stories have something of a self-congratulatory tone to them, highlighting the adoption of BWCs as indicative of proactive police practices, their ability to adapt to the new visual reality, and their own technological and media savvy. In this narrative, BWCs are a police initiative, born of good policing.

11 As Robyn Maynard (2017) points out, this act of naming anti-black racism as a uniquely American issue has a long history in Canada. Preferring to celebrate its history as a destination on the Underground Railroad and, thus, as the place of freedom over its own slave-owning past, Canadian myth-making projects obscure the history of anti-black racism in Canada and, subsequently, present Canada as a place where racism is "relatively benign" and Canadian policing is "a race-neutral practice" (Maynard 2017: 24; 86). Canadian police officers' statements about the difference between their work and that of their counterparts in the US can be interpreted as implicated in, and sustaining, this national myth. 
As these "origin stories" further suggest, Canadian police are not insensitive to popular demands for cameras, nor to the general climate of "policing on camera" that has produced the desire for such officerworn technology in the first place. But, as Emmeline Taylor and Murray Lee (2019: 967) observe, "officers, perhaps unsurprisingly, judge citizens' behavior as being more in need of improvement rather than their own." This was certainly the case for the police we interviewed, for whom the key objective of BWCs is not to address racism per se but to address calls for greater accountability in the context of public perceptions of racist policing. Police thus justified the need for BWCs by presenting them as a tool they can use to not only deflect criticism but also actively demonstrate their professionalism. The following offers an example of this commonly expressed argument:

Let's say he [the suspect] and I are in a call... and we're fighting. I'm trying to get control of him, he has assaulted me, I'm trying to get control. We break, step back to take a breath, I go to grab him, I give him a shot and he goes down. Right then when we step back to take a breath, you come around the corner with your iPhone and start filming. Now all you see is me grab him, drop him, and go to the ground and cuff him. So you think, oh my god, that's police brutality... Anything that could have happened to precipitate that situation is not caught on your video. All you catch is the end result.... It's like a hockey game where the ref always ends up catching the retaliation rather than the first hit. (Participant 27)

We heard many such sports-inspired metaphors about citizen videos, which police complained decontextualized the encounters and, therefore, transformed the public into "armchair quarterbacks" (Participant 4) who did not understand what it is that police do. In short, according to our police participants, citizen-shot videos are bad press, producing an unnecessarily poor picture of policing and, in the words of one officer, "fuel[ing] the flames of the haters" (Participant 44). Newell's (2019) analysis of American police responses to citizen videos draws a similar conclusion. As he argues, and our study confirms, BWCs are appealing for police because they believe that video captured through this technology will show that the public is drawing inaccurate conclusions based on incomplete images (see also Sandhu 2017; Sandhu and Haggerty 2017). By extension, having cameras that record an encounter from the beginning of the policecitizen interaction will show that police are justified in their use of force and reasonable in the exercise of their discretion. ${ }^{12}$

This police approach achieves two things. First, it sets up the public as untrustworthy consumers of images of public policing. This construction of the public as suspect also means that, second, police tended to believe that criticism of their work needed to be corrected rather than addressed on its face. BWCs are, therefore, embraced by police as a pedagogical tool for the public in order to help them right their inaccurate views of policing.

This view of the pedagogical value of BWCs was especially apparent with respect to race. Although, as indicated above, the police in our study tended to mute the racialized demands for the technology, they were more vocal on the ways in which having cameras would exonerate them from what they saw as the unfounded allegations of racial profiling. Indeed, police actively welcomed cameras as a means to put claims of racist policing to rest. This view was apparent even among front-line officers whom we might say offered direct evidence of their own racism:

Participant 12: There was one gentleman, he's an Indian male, and I recall vividly he went on and on about how racist I am. I love when he does that because you get to watch

\footnotetext{
12 This view is complicated by debates on whether BWCs should be on all the time (the view of most community participants) or only turned on at the moment a civilian-police encounter becomes a formal "incident" (the view of the police, as well as privacy advocates). While important, this debate is beyond the scope of this paper. Suffice to say that all Canadian police services that have experimented with BWCs have developed policies in which cameras are only turned on at the discretion of the officer as informed by general guidelines established by the police service.
} 
him - you watch the video of me pulling over the driver - I pull him over for an illegal left turn or because of whatever traffic infraction or just to check sobriety. The first person to mention race is the person accusing me of racism. I guess we know who the racist is here, sir or ma'am. So, I actually do like it [the body-worn camera] because what did [I] do? [I] talked about [my] job, talked about the task at hand, the guy's drunk yada yada - this is 'cause [sic] you're racist?! What would lead you to that conclusion? Because of my skin colour? Well that's not how this works. I actually did like it, I do get accused of it a lot. This puts it away. You can't say I dropped the N bomb on anybody or whatever. It gets rid of that ridiculous argument very quickly.

Participant 44: My problem is that am I racist? On paper? No.... Like, I would never... I can't say never because I've probably done it. But I've never gone to someone like, "you dirty n---,"13 I've never gone and done that because it's just.... Certainly, there could be comments made off-scene or in the car, "What a breed of people," something to that effect.

As these examples illustrate, for police, citizen complaints of racial profiling are unsubstantiated because they lack overt evidence of specifically racialized motivations or utterance of racially offensive language, such as using the "N-word." The latter seemed especially important to police and was mentioned often in the interviews. Even if admittedly said off camera, the fact that this offensive word was not expressly used in an encounter was considered to be evidence of race-free policing. In these police narratives, racism is a proven absence: if it is not documented, including by surveillance video, it doesn't exist.

In constructing racism as an absence, police were also relying implicitly on the ways that the particular mechanics of BWCs will structure what is, and what is not, rendered visible through filmic evidence of their work. As sophisticated as the mobile technologies may be, they are still both spatially and, perhaps more importantly, temporally specific captures of a moment. As Smith (2015) observed about the surveillant state more generally, this excludes from view the state and the role it, and its agents, play in establishing the racialized context for any given encounter between surveyors and those subjected to the gaze of surveillance. On the contrary, as imagined by police and as dictated by the technology, BWCs will capture only specific encounters and, for the police, it is only this encounter, not the broader temporal and spatial context, that signifies. ${ }^{14}$ The racial significance of this technologically driven feature of BWCs, and the gap it produces in police and community expectations of what cameras can do, is evident in the juxtaposition of the following two quotes, the first from a member of an Indigenous legal clinic in Region 3, the second from a patrol officer in Region 1:

Participant 33: They [Indigenous peoples] are not just, you know, I'm bored with my life and I'm going to be a badass or whatever. They are dealing. They have this burden of colonization and the residential schools, the sixties scoop, you name it! The person you see there is not just that person. They are a whole history coming down the line. (emphasis added)

Participant 43: Nothing in the video shows that I was racially profiling the intoxicated Aboriginal man who was yelling obscenities down [-] Avenue at the business people. He can accuse me of that, the video doesn't... it shows just what I dealt with, right. (emphasis added).

The difference between these two perspectives of a racialized police-citizen encounter is startling. For overpoliced communities, such as Indigenous communities, a momentary encounter with a police officer is thoroughly saturated with the long and painful history of colonialism, including the ways it manifests

${ }^{13}$ Note that the officer used the "N-word" here. We have chosen not to repeat it.

${ }^{14}$ For a postcolonial analysis of this temporal disjuncture, see Glasbeek, Roots, and Alam (2019). 
concretely and in living memory through things like land theft, residential schools, child scoops, family disintegration, over-incarceration, and physical violence by state officials, including police officers. Thus, in any given encounter, history matters. Police, on the other hand, focus only on their in-real-time engagement with citizens as the single defining snapshot of good or bad policing. In the second example, rather than "a whole history coming down the line," what the officer saw was an out-of-place intoxicated Indigenous man disturbing the peace. The racially constructed circumstances that produced this moment are not only invisible but are also impossible to capture on video. The accusation of racial profiling can thus be dismissed as unfounded. As long as police officers do not use racially specific offensive language or demonstrate explicit racial motivation, and as long as their use of force can be defended as part of the professional elements of their job performance, there is no racism, and any accusation to the contrary is unwarranted. BWCs, police expect, will uphold this definition of bias-free policing, by providing evidence of what police do not do. BWCs are attractive to police not just for what they will render visible, but equally, if not more importantly, for what they will not see.

\section{Conclusion}

The fundamental premise of "The Lawn Chair," the Scandal episode cited at the opening of this article, was that cameras offered a neutral intervention into heated racial politics, promising to project an unbiasedand, therefore, potentially recuperative - truth onto a divided landscape (Verica 2015). While this position may be rightly critiqued for its blind faith in the "mechanical objectivity" of the camera image (Brucato 2015: 459), as well as for its neglect of the "racialized ways of seeing" that profoundly affects the impact of video images of police work (Beutin 2017), it nonetheless articulates a goal for BWCs that takes seriously racialized policing and the increasingly heavy toll it is taking on civil society. But, what can be said about BWCs if even this premise is absent? What can BWCs hope to achieve if there is no formal recognition of the racial landscape that has prompted populist demands for such cameras in the first place? As we have shown, in Canada, police insist that such divisive approaches to policing are an American problem, yet they have simultaneously engaged in pilot projects of BWCs as something with which contemporary police must now contend. This has necessitated the crafting of origin stories that de-racialize the context for BWCs. Distancing themselves from their American counterparts, Canadian police have taken refuge in a uniquely Canadian story of tolerance and multiculturalism, even amidst ample evidence of racist policing as an equally divisive Canadian problem (Ontario Human Rights Commission 2018, 2017/2018, 2017; Marcoux and Nicholson 2018; Maynard 2017; Hudson and Khogali 2018; Comack 2012). As we have suggested, the fact that Canadian police services have been slow, at best, to roll out BWCs, despite public demands for them, is indicative of the ways in which the urgency of body-worn cameras, as neatly captured by Scandal, is absent in Canada, where the potential of "seeing" racism has been rendered unnecessary in police explorations with this new surveillant technology.

We return, then, to the politics of not-seeing as an important part of the future of body-worn cameras. As we have shown, while Canadian police acknowledge that there is a public perception of racist policing, they insist that this perception is incorrect. Police thus construct the public as suspect consumers of images of policing on camera and embrace body-worn cameras as a pedagogical tool, able to correct a public that is unable to properly understand their work. To do so, however, means they have an interest in very carefully managing the story of what cameras will and will not see. For police, body-worn cameras can demonstrate an absence of racism, whether through the non-utterance of offensive language or through the privileging of temporally limited encounters over longer histories of state violence against racialized communities. The very racialized tensions that community members hope the new mobile technologies can make visible are precisely those that police-worn technologies cannot capture. Not only is the police point of view "legally and culturally privileged" in the use of police body-worn cameras, but the historical and deeply racialized nature of the relationship between the surveillance state and its subject populations is impossible to capture in temporally and spatially specific video imagery. What body-worn cameras can make visible may be, in the end, less important to the ongoing struggle against racialized policing than what they do not see. 


\section{Postscript}

Since this article went to publication, much has changed. Canada, like many countries around the world, was rocked by the killing of George Floyd in Minneapolis on May 25, 2020, as well as by the uprisings that followed demanding racial justice, including, if not especially, a radical rethinking of police. This racial reckoning occurred at the same time that several black, Indigenous, and people of colour were killed by police across the country while police brutality, especially against Indigenous people, was brought to light through video witnessing. As Canadian politicians and police organizations tripped over each other in their rush to respond by publicly acknowledging systemic racism in policing, body-worn cameras reappeared on the Canadian landscape. Canadian Prime Minister Justin Trudeau called upon the federal police service, the RCMP, to deploy BWCs. A similar call was heard in Toronto where, after being stalled for years, BWCs were championed by the mayor as a direct response to local protests for racial justice and expedited by the TPS Board, so that a full roll-out of cameras is now expected to occur before the end of 2020. Other police jurisdictions that had initially decided against cameras are now re-exploring them or deciding to implement them, including Montreal, Halifax, Hamilton, Ottawa and Peel Region (part of the Greater Toronto Area).

While this renaissance of BWCs in Canada is worthy of deeper exploration, here it suffices to note that this development fits with one of the key arguments made in this article, namely that the renewed interest in BWCs is animated by a newfound urgency with respect to acknowledging racism and the consequent newly pressing need to be seen addressing the specific problem of racist policing. It is precisely this recognition that has made BWCs re-emerge as an imperative. As they were in Scandal half a decade ago now, BWCs are being presented to the Canadian public as a way forward for a racially divided Canada. Any future evaluations of BWCs in Canada, including assessments of whether they "work," must treat their role in the policing of race as the centre of the analysis.

\section{Acknowledgments}

The authors are deeply grateful for the generous and helpful feedback from the two anonymous reviewers for Surveillance \& Society.

\section{References}

Adams, Ian, and Sharon Mastracci. 2017. Visibility is a Trap: The Ethics of Police Body-Worn Cameras and Control. Administrative Theory \& Praxis 39 (4): 313-328.

Andrew-Gee, Eric. 2014. YouTube Video Had Huge Impact on Sammy Yatim Case. Toronto Star, July 27. https://www.thestar.com/news/crime/2014/07/27/youtube video had huge impact on sammy yatim case.html [accessed April 8, 2019].

Beare, Margaret. 2014. The Failures of Police Legitimacy: Attacks from Within. In Globalisation, Criminal Law and Criminal Justice: Theoretical, Comparative, and Transnational Perspectives, edited by Valsamis Mitsilegas, Peter Alldridge, and Leonidas Cheliotis, 87-111. Oxford: Hart Publishing.

Beutin, Lyndsey. 2017. Racialization as a Way of Seeing: The Limits of Counter-Surveillance and Police Reform. Surveillance \& Society 15 (1): 5-20.

Brown, Gregory R. 2016. The Blue Line on Thin Ice: Police Use of Force Modifications in the Era of Cameraphones and YouTube. The British Journal of Criminology 56 (2): 293-312.

Browne, Simone. 2015. Dark Matters: On the Surveillance of Blackness. Durham, NC: Duke University Press.

Brucato, Ben. 2015. Policing Made Visible: Mobile Technologies and the Importance of Point of View. Surveillance \& Society 13 (3/4): 455-473.

2016. Standing by Police Violence: On the Constitution of the Ideal Citizen as Sousveiller. American Studies Journal 61, doi: 10.18422/61-06.

Bud, Thomas K. 2016. The Rise and Risks of Police Body-Worn Cameras in Canada. Surveillance \& Society 14 (1): $117-121$.

Butler, Judith. 1993. Endangered/Endangering: Schematic Racism and White Paranoia. In Reading Rodney King, Reading Urban Uprising, edited by R. Gooding-Williams, 15-22. New York: Routledge.

CBC News. 2016. 75\% of City Residents Agree Toronto Police Should Wear Body Cameras: Poll. February 3. http://www.cbc.ca/news/canada/toronto/police-poll-cameras-1.3432508 [accessed April 8, 2019].

- 2019. Calgary Police Now Have 1,150 Body-Worn Cameras on Front-Line Officers. August 13. https://www.cbc.ca/news/canada/calgary/calgary-police-body-cams-second-attempt-1.5245785 [accessed October 19, 2019 ]. 
Chan, Wendy, and Dorothy Chunn. 2014. Racialization, Crime, and Criminal Justice in Canada. Toronto: University of Toronto Press.

Comack, Elizabeth. 2012. Racialized Policing: Aboriginal People's Encounters with the Police. Halifax, CA: Fernwood.

Crenshaw, Kimberle, and Gary Peller. 1993. Reel Time/Real Justice. In Reading Rodney King, Reading Urban Uprising, edited by Robert Gooding-Williams, 56-70. New York: Routledge.

Doll, Jayme, and Erika Tucker. 2016. 2 Calgary Police Officer-Involved Shootings Renew Call for Body Worn Cameras. Global News, September 19. https://globalnews.ca/news/2950286/2-calgary-police-officer-involved-shootings-renew-calls-forbody-worn-cameras/ [accessed April 8, 2019].

Ericson, Richard V. 1995. The News Media and Account Ability in Criminal Justice. In Accountability for Criminal Justice: Selected Essays, edited by Phillip Stenning, 135-161. Toronto: University of Toronto Press.

Evans, Richard. 2015. "The Footage is Decisive": Applying the Thinking of Marshall McLuhan to CCTV and Police Misconduct. Surveillance \& Society 13 (2): 218-232.

Farmer, Ashley K., and Ivan Y. Sun. 2016. Citizen Journalism and Police Legitimacy: Does Recording the Police Make a Difference? In The Politics of Policing: Between Force and Legitimacy, edited by Mathieu Deflem, 239-256. Bingley, UK: Emerald Group Publishing Limited.

Fine, Sean. 2018. Appeal Court Upholds James Forcillo's Conviction, Sentence in Sammy Yatim Case. Globe \& Mail, April 30. https://www.theglobeandmail.com/canada/article-appeal-court-upholds-conviction-sentence-against-toronto-police/ [accessed April 8, 2019].

Fiske, John. 1998. Surveilling the City: Whiteness, the Black Man and Democratic Totalitarianism. Theory, Culture \& Society 15 (2): $67-88$.

Gates, Kelly. 2011. Our Biometric Future: Facial Recognition Technology and the Culture of Surveillance. New York: New York University Press.

- 2016. The Work of Wearing Cameras: Body-Worn Devices and Police Media Labor. In The Routledge Companion to Labor and Media, edited by Richard Maxwell, 252-264. New York: Routledge.

Gillis, Wendy. 2015. No Charges Against Peel Police in Death of Jermaine Carby. Toronto Star, July 21. https://www.thestar.com/news/crime/2015/07/21/no-charges-against-peel-police-in-death-of-jermaine-carby.html [accessed April 8, 2019].

Glasbeek, Amanda, Katrin Roots, and Mariful Alam. 2019. Postcolonialism, Time, and Body Worn Cameras. Surveillance \& Society 17 (5): 743-746.

Global News. 2018. Fredericton Police to Add Body-Worn Cameras to Traffic Unit. April 10. https://globalnews.ca/news/4135718/fredericton-police-to-add-body-worn-cameras-to-traffic-unit/ [accessed October 18, 2019].

Goldsmith, Andrew. 2010. Policing's New Visibility. British Journal of Criminology 55 (5): 914-934.

Government of British Columbia. 2019. British Columbia Provincial Policing Standards, Subject: 4.2.1 Body Worn Cameras. https://www2.gov.bc.ca/assets/gov/law-crime-and-justice/criminal-justice/police/standards/4-2-1-body-worn-camerasequipment.pdf [accessed January 6, 2020].

Haggerty, Kevin D., and Richard V. Ericson. 2000. The Surveillant Assemblage. The British Journal of Sociology 51 (4): $605-622$.

Hasham, Alyshah. 2016. Const. James Forcillo Sentenced to 6 years in Sammy Yatim Shooting. Toronto Star, July 28. https:/www.thestar.com/news/crime/2016/07/28/const-james-forcillo-sammy-yatim-shooting-sentence.html [accessed April $8,2019]$.

Hudson, Sandra, and Yusra Khogali. 2018. We Will Win: Black Lives Matter - Toronto. In Race and Racialization: Essential Readings, 2nd ed., edited by Tania Das Gupta, Carl E. James, Chris Andersen, Grace-Edward Galabuzi, and Roger C. A. Maaka, 695-713. Toronto: Canadian Scholars Press.

Huey, Laura, Kevin Walby, and Aaron Doyle. 2006. Cop Watching in the Downtown Eastisde: Exploring the Use of (Counter) Surveillance as a Tool of Resistance. In Surveillance and Security: Technological Politics and Power in Everyday Life, edited by Torin Monahan, 149-165. New York: Routledge.

Huncar, Andrea. 2017. Indigenous Women Nearly 10 Times More Likely to be Street Checked by Edmonton Police, New Data Shows. CBC News, June 27. http://www.cbc.ca/news/canada/edmonton/street-checks-edmonton-police-aboriginal-blackcarding-1.4178843 [accessed April 8, 2019].

Iacobucci, Frank. 2014. Police Encounters with People in Crisis: An Independent Review Conducted by the Honourable Frank Iacobucci for Chief of Police William Blair. Toronto Police Service. http://www.tpsreview.ca/docs/Police-Encounters-WithPeople-In-Crisis.pdf [accessed April 8, 2019].

Jago, Robert. 2018. The Deadly Racism of Thunder Bay. Walrus Magazine, September 13. https://thewalrus.ca/the-deadly-racismof-thunder-bay/ [accessed October 18, 2019].

Laming, Erick. 2017. Why Canadian Police Services are Not Adopting Body Cameras. Huffington Post, January 26. https://www.huffingtonpost.ca/erick-laming/police-body-cameras-canada_b_14410866.html [accessed April 8, 2019 ].

Lippert, Randy, and Bryce Clayton Newell. 2016. Debate Introduction: The Privacy and Surveillance Implications of Police Body cameras. Surveillance \& Society 14 (1): 113-116.

Lum, Cynthia, Megan Stoltz, Christopher S. Kper, and J. Amber Scherer. 2019. Research on Body-Worn Cameras: What We Know, What We Need to Know. Criminology \& Public Policy 18: 93-118.

Marcoux, Jacques, and Katie Nicholson. 2018. Deadly Force: Fatal Encounters with Police in Canada: 2000-2017. CBC News. https://newsinteractives.cbc.ca/longform-custom/deadly-force [accessed October 18, 2019].

Mateescu, Alexandra., Alex Rosenblat, and danah boyd. 2016. Dreams of Accountability, Guaranteed Surveillance: The Promises and Costs of Body-Worn Cameras. Surveillance \& Society 14 (1): 122-127.

Maynard, Robyn. 2017. Policing Black Lives: State Violence in Canada from Slavery to the Present. Halifax, CA: Fernwood. 
Mayor, Lisa, and Gillian Findlay. 2018. "Neglect of Duty" Found in Review of Thunder Bay Police Investigation into Death of Indigenous man. CBC News, March 4. https://www.cbc.ca/news/canada/thunder-bay/stacey-debungee-police-investigationindependent-report-thunder-bay-1.4559221 [accessed April 8, 2019].

Monahan, Torin. 2006. Counter-Surveillance as Political Intervention? Social Semiotics 16 (4): 515-534.

Newell, Bryce. 2016. Collateral Visibility: A Socio-Legal Study of Police Body-Camera Adoption, Privacy, and Public Disclosure in Washington State. Indiana Law Journal 92 (4): 1329-1399.

. 2019. Context, Visibility and Control: Police Work and the Contested Objectivity of Bystander Video. New Media and Society 2 (1): 60-76.

Office of the Independent Police Review Director (OIPRD). 2018. Broken Trust: Indigenous People and the Thunder Bay Police Service. December. http://oiprd.on.ca/wp-content/uploads/OIPRD-BrokenTrust-Final-Accessible-E.pdf [accessed April 8, 2019].

Office of the Privacy Commissioner of Canada. 2015. Guidelines for the Use of Body-Worn Cameras by Law Enforcement Authorities. https://www.priv.gc.ca/en/privacy-topics/public-safety-and-law-enforcement/gd bwc 201502// [accessed April 8, 2019].

Ontario Human Rights Commission. 2017. Public Interest Inquiry into Racial Profiling and Discrimination by the Toronto Police Service. http://www.ohrc.on.ca/en/public-interest-inquiry-racial-profiling-and-racial-discrimination-tps [accessed April 8, 2019].

- 2017/18. Annual Report. http://ohrc.on.ca/sites/default/files/OHRC AR 2017.pdf [accessed April 8, 2019].

. 2018. A Collective Impact: Interim Report on the Inquiry into Racial Profiling and Racial Discrimination of Black Persons by the Toronto Police Service. November. http://ohrc.on.ca/en/public-interest-inquiry-racial-profiling-and-discriminationtoronto-police-service/collective-impact-interim-report-inquiry-racial-profiling-and-racial-discrimination-black [accessed April 8, 2019].

Ontario Justice Education Network. 2016. The Death of Sammy Yatim and the Trial of James Forcillo. InFocus. http://ojen.ca/wpcontent/uploads/2016/11/In-Focus- Yatim-and-Forcillo TeacherFinal.pdf [accessed April 8, 2019].

Rodriguez, Miro. 2014. Caught on Camera: How Citizen Video Told Sammy Yatim's Story. Ryerson Review of Journalism, March 27. https://rri.ca/caught-on-camera-how-citizen-video-told-sammy-yatims-story/ [accessed April 8, 2019 ].

Sandhu, Ajay. 2016. Camera-Friendly Policing: How the Police Respond to Cameras and Photographers. Surveillance \& Society, 14 (1): 78-89.

. 2017. "I'm Glad that was on Camera": A Case Study of Police Officers' Perceptions of Cameras. Policing and Society 29 (2): 1-13.

Sandhu, Ajay, and Kevin D. Haggerty. 2017. Policing on Camera. Theoretical Criminology 21 (1): $78-95$.

Schaefer, Brian, and Kevin Steinmetz. 2014. Watching the Watchers and McLuhan's Tetrad: The limits of Cop-Watching in the Internet Age. Surveillance \& Society 12 (4): 502-515.

Skolnick, Jerome H., and James J. Fyfe. 2005. The Beating of Rodney King. In Policing: Key Readings, edited by Tim Newburn, 568-580. Portland, OR: Willan Publishing.

Smith, Andrea. 2015. Not-Seeing: State Surveillance, Settler Colonialism, and Gender Violence. In Feminist Surveillance Studies, edited by Rachel E. Dubrofsky and Shoshana Amielle Magnet, 21-38. Durham, NC: Duke University Press.

St. Louis, Ermus, Alana Saulnier, and Kevin Walby. 2019. Police Use of Body-Worn Cameras: Challenges of Visibility, Procedural Justice, and Legitimacy. Surveillance \& Society 17 (3/4): 305-321.

Talaga, Tanya. 2017. Seven Fallen Feathers: Racism, Death and Hard Truths in a Northern City. Toronto: House of Anansi Press.

Tator, Carol, and Frances Henry. 2006. Racial Profiling in Canada: Challenging the Myth of “A Few Bad Apples.” Toronto: University of Toronto Press.

Taylor, Emmeline, and Murray Lee. 2019. Points of View: Arrestees' Perspective on Police Body-Worn Cameras and Their Perceived Impact on Police-Citizen Interactions. British Journal of Criminology 59 (4): 958-978.

Toronto Police Service. 2013. The Police and Community Engagement Review (The PACER Report). http://www.torontopolice.on.ca/publications/files/reports/2013pacerreport.pdf [accessed April 8, 2019].

Verica, Tom, dir. 2015. Scandal. Season 4, episode 14, The Lawn Chair. Aired March 5, on ABC.

Warnica, Richard. 2015. The Life and Bloody Death of Andrew Loku: Toronto Police Officer's Face "Went White as a Ghost" After Shooting. National Post, July 17. https://nationalpost.com/news/toronto/the-life-and-bloody-death-of-andrew-loku [accessed April 8, 2019].

Wasserman, Howard. 2015. Moral Panics and Body Worn Cameras, and Epilogue. Washington University Law Review 92 (3): $831-$ 848.

Wing, Nick. 2014. Obama Wants to Help Buy 50,000 Body Cameras for the Nation's 630,000 Police Officers. Huffington Post, December 1. http://www.huffingtonpost.ca/entry/obama-police-body-cameras n 6250146 [accessed April 8, 2019].

Wortley, Scot, and Julian Tanner. 2003. Data, Denials, and Confusion: The Racial Profiling Debate in Toronto. Canadian Journal of Criminology and Criminal Justice. 45 (3): 367-390. 